\title{
Pengaruh Model Pembelajaran Kontekstual dan Minat Belajar terhadap Kemampuan Menulis Puisi
}

\author{
Meria Sri Dewi Priatna \\ Fakultas Pascasarjana, Universitas Indraprasta PGRI \\ Jalan Nangka No. 58 C/TB. Simatupang, Tanjung Barat, Jakarta Selatan 12530 \\ meriasridewi@gmail.com
}

\begin{abstract}
The explanatory study was aimed to show the influence of contextual learning model and interest in learning to the ability to write poetry. The study used two-group design, pretest-posttest, with a population of junior high school students in the Cibinong sub-district, Bogor Regency, and through an experiment technique, obtained a sample of 80 people. this study using the help of SPSS 20.0 software. The results of research to prove that contextual learning model and interest in learning affect the poetry writing skill.
\end{abstract}

Keywords: ability to write poetry, contextual learning model, interest in learning

\begin{abstract}
Abstrak
Penelitian ini bertujuan untuk menunjukkan pengaruh model pembelajaran kontekstual dan minat belajar terhadap kemampuan menulis puisi. Penelitian mempergunakan design two group, pretest, posttest design, dengan populasi siswa SMP Negeri di kecamatan Cibinong, Kabupaten Bogor, dan melalui teknik eksperimen, diperoleh sampel sebesar 80 orang. Penelitian ini menggunakan bantuan software SPSS 20.0. Hasil penelitian membuktikan bahwa model pembelajaran kontekstual dan minat belajar berpengaruh terhadap kemampuan menulis puisi.
\end{abstract}

Kata Kunci: kemampuan menulis puisi, model pembelajaran kontekstual, minat belajar

\section{PENDAHULUAN}

Berbahasa merupakan kegiatan rutin yang dilakukan oleh manusia. Berbahasa bukanlah kegiatan sulit. Setiap orang mampu berbahasa untuk berkomunikasi. Sebagaimana Abidin mengemukakan bahawa alat utama dalam bekomunikasi adalah bahasa. Bahasa membantu manusia untuk berinteraksi antarsesama. Manusi juga dapat mengembangkan budaya melalui bahasa. Bahasa mampu memdorong kemajuan dari segala segi di muka bumi. Oleh sebab itulah, bahasa dikatakan sebagi media komunikasi yang amat viral (Abidin, 2009: 3).

Kehadiran bahasa tidak bisa dipisahkan dengan sastra karena pada prinsipnya dua hal tersebut adalah sesuatu hal yang tidak terpisahkan dalam kebudayaan manusia. Keduanya saling memberi dan menerima, sebagaimana dikemukakan Aftarudin dalam Jamaluddin dalam Sari, sastra merupakan seni berkomunikasi yang menggunakan bahasa sebagai medianya. Keberadaan Bahasa sangat wajib untuk eksistensi sastra. Melalui bahasa, sastra, dapat berupa sastra lisan maupun tertulis (Sari, 2017). Di satu pihak, sastra menjadi salah satu bentuk pengungkapan bahasa dan bahasa terasa kehidupannya karena sentuhan estetis unsur-unsur sastra. Selain itu, bahasa merupakan alat yang paling komunikatif bagi para penyair untuk mencurahkan getaran pikiran dan gejolak perasaannya. Dengan 
bahasa pula mereka bisa menangkap maksud dan perasaan orang lain dan dengan bahasa mereka dapat menggambarkan situasi yang sedang terjadi di masyarakat yang membedakannya dengan bentuk-bentuk pengunkapan nonsastra. Adapun genre sastra yang sudah dikenal secara umum meliputi puisi, prosa ( cerita pendek, novel), dan karya-karya drama (naskah).

Kemampuan berbahasa dan bersastra yang meliputi aspek mendengarkan, berbicara, membaca, dan menulis sangat penting untuk dikuasai terutama oleh siswa sebagai generasi muda. Dari kemampuan tersebut akan lahir keterampilan yang dapat diperoleh dengan cara banyak berlatih. Hal ini tentunya dapat dilaksanakan di lembaga formal (sekolah) yang merupakan sarana paling tepat untuk mendapatkan keterampilan yang dibutuhkan. Dari empat keterampilan yang ada, penulis akan membahas salah satu aspek mengenai keterampilan, yaitu menulis, khususnya menulis puisi.

Guru mempunyai peranan yang sangat penting dalam menentukan model, strategi, metode, media, peralatan, dan fasilitas lainnya untuk proses pembelajaran serta bagaimana cara mengemas informasi supaya mudah dipahami oleh siswa. Selain itu, minimnya sarana dan prasarana juga sangat memengaruhi proses belajar dan mengajar sehingga tujuan pembelajaran tidak dapat dicapai secara maksimal. Peranan guru sangat dibutuhkan untuk meningkatkan minat siswa agar termotivasi dan tertarik untuk belajar Bahasa Indonesia. Guru dituntut memiliki pengetahuan yang mendalam tentang materi yang disampaikan dan mampu menggunakan metode pembelajaran yang sesuai dengan karakteristik materi yang akan disampaikan. Dengan begitu, siswa akan memiliki minat belajar tinggi dan sangat mungkin akan belajar dengan sungguh-sungguh. Menurut Dhan dan Rianto, minat disebut pula konsentrasi atau perhatian. Konsentrasi adalah proses pemusatan psikis untuk menhadapi tugas belajar, sedangkan perhatian adalah ketertarikan pada suatu maalah yang sedang dipelajari. Seseorang yang belajar dengan penuh minat akan berusaha mempelajari dengan penuh perhatian dan dengan semangat belajar tinggi, mereka akan senantiasa memotivasi diri untuk tertarik pada materi yang dipelajari, sehingga prestasi belajar meningkat (Musaljon, 2019).

Jika kita menyimak kenyataan yang dihadapi dunia pendidikan, khususnya pada Sekolah Menengah Pertama di Kecamatan Cibinong kabupaten Bogor, pendidikan sepenuhnya dapat membantu perkembangan kepribadian siswa secara optimal, di antaranya prestasi belajar tinggi dan bahkan setiap tahun pelajaran ada siswa yang berhasil, baik berhasil dalam pengertian naik kelas, maupun berhasil dalam pengertian lulus dalam menempuh ujian nasional. Begitu pula dalam aktivitas belajar. Siswa yang mempunyai minat belajar tinggi cenderung menaati peraturan sekolah.

Keberhasilan yang diperlihatkan oleh siswa dapat disebabkan oleh berbagai faktor, baik itu dari luar diri siswa itu sendiri, maupun dari dalam dirinya. Faktor yang berasal dari luar diri siswa itu sendiri di antaranya faktor media pembelajaran. Dalam kenyataannya masih banyak guru yang beranggapan bahwa masalah belajar adalah tugas anak, maka lepaslah tanggung jawab guru dalam memperhatikan semangat belajar siswanya. Akhirnya, tanpa disadari siswa mencari lingkungan di luar rumah yang tidak yang semuanya baik. Minat belajar merupakan salah satu faktor penting dalam menunjang keberhasilan pendidikan dan pengajaran. Untuk

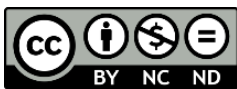


dapat melaksanakan hal itu, para pendidik khususnya, harus dapat membina dan memacu semangat belajar anak, sehingga waktu yang dibutuhkan untuk belajar anak tidak sia-sia. Anak akan belajar dengan baik apabila mempunyai minat belajar yang besar. Jika seorang anak atau seorang murid memiliki rasa belajar yang tinggi, maka ia akan cepat mengerti dan mengingatnya. Guru yang berhasil membina kesediaan belajar murid-muridnya berarti telah melakukan suatu hal yang terpenting yang dapat dilakukan demi kepentingan belajar murid-muridnya. Sebab, minat tidak dapat muncul tiba-tiba, melainkan perlu proses pembelajaran.

Menurut pengamatan, menulis puisi bagi sebagian siswa bukanlah hal yang mudah. Seseorang menulis puisi karena ingin mencurahkan atau menceritakan pengalaman yang dirasakannya. Menulis puisi tidak hanya sekadar menulis, tetapi menulis puisi memerlukan penghayatan dan keseriusan dalam proses pembuatannya. Puisi merupakan luapan emosi seseorang yang dituangkan ke dalam kata, simbol atau lambang yang diolah dengan sungguh-sungguh, sehingga menimbulkan keindahan. Karena itu, penulis puisi harus peka terhadap apa yang dilihat, dirasa, dan didengar.

Tarigan mengemukakan, menulis merupakan proses pelukisan lambinglambang yang menggambarkan bahasa sehingga dapat dipahami oleh orang lain. Pendapat tersebut menunjukkan bahwa dengan tulisan, dapat terjadi komunikasi antara penulis dan pembaca. Hal ini dapat terjadi apabila penulis dan pembaca memahami lambang-lambang grafik yang dipergunakan untuk menulis tersebut (Tarigan, 1994). Pradopo mengemukakan,'Puisi itu merupakan rekaman dan interpretasi pengalaman manusia yang penting, diubah dalam wujud yang paling berkesan." Dengan adanya puisi setiap orang dapat mengutarakan pengalamannya dengan menggunakan kata-kata indah sehingga mempunyai makna yang berkesan dan bisa dinikmati oleh setiap orang (Pradopo, 2000).

Mampu menulis puisi merupakan standar kompetensi yang harus dimiliki siswa kelas VIII. Kemampuan menulis puisi harus dibina dengan terus-menerus sehingga siswa memiliki kemampuan menulis puisi dengan baik. Namun, pada kenyataannya masih banyak siswa yang belum mampu menulis puisi, bahkan tidak sedikit siswa yang beranggapan bahwa menulis puisi adalah kegiatan yang tidak bermanfaat dan puisi hanyalah seni yang tidak memberikan ilmu apa-apa, serta tidak terlalu berpengaruh di dalam kehidupan masyarakat.

Kenyataan di atas tentu harus menjadi perhatian para guru karena pembelajaran sastra dimaksudkan untuk meningkatkan kemampuan siswa dalam mengapresiasi berbagai ragam karya sastra, terutama dalam menulis puisi, sedangkan mengapresiasi karya sastra (menulis puisi) berkaitan erat dengan latihan mempertajam perasaan, penalaran, dan daya khayal, serta kepekaan terhadap masyarakat, kebudayaan, dan lingkungan hidup. Oleh karena itu, guru harus mengetahui penyebab siswa tidak mampu menulis puisi dan mencari penyebab ketidakberhasilan pembelajaran menulis puisi tersebut, sehingga guru bisa menemukan model pembelajaran yang cocok digunakan dalam pembelajaran puisi. Dengan menggunakan model pembelajaran yang cocok dan sesuai dengan kondisi siswa atau kendala-kendala yang dihadapinya, siswa akan dengan mudah mempelajari puisi terutama tentang menulis puisi. Hal tersebut sejalan dengan yang 
dikemukakan oleh Anshori (2003: 48), rendahnya menulis di kalangan siswa berhubungan erat dengan sistem pembelajaran (Kartika, 2014).

Dalam mengatasi ketidakmampuan siswa menulis puisi harus ada model pembelajaran yang diterapkan dalam pembelajaran puisi. Salah satunya, yaitu model pembalajaran kontekstual. Suyatno dalam Ardiana mengemukakan bahwa pembelajaran kontekstual merupakan usaha menghubungkan materi pembalajaran dengan situasi atau dunia nyata yang dekat dengan siswa terkait aplikasinya dalam kehidupan sehari-hari (Ardiana, 2001). Model pembelajaran kontekstual menurut Sanjaya, "Belajar dalam kontekstual bukan sekedar mendengarkan dan mencatat, tetapi belajar adalah proses pengalaman secara langsung." Dengan model pembelajaran kontekstual ini siswa dapat menuangkan pegalamannya secara langsung melalui menulis puisi (Sanjaya, 2008).

Penulis memilih penelitian tentang model pembelajaran kontekstual dan minat belajar terhadap kemampuan menulis puisi karena berdasarkan latar belakang yang dikemukakan di atas bahwa siswa masih kurang berminat untuk menulis terutama menulis puisi.

\section{METODE}

Penelitian ini menggunakan desain two group, pretest, posttest design, dengan populasi siswa SMP Negeri di Kecamatan Cibinong, sejumlah 800 orang sebagai subjek penelitian. Sampel diambil dari satu kecamatan, sejumlah 80 responden. Variabel kemampuan menulis puisi adalah proses intelektual dalam mengorganiasi bahasa, kepekaan, dan kecerdasan (Jabrohim, Anwar, \& Sayuti, 2009).

Variabel model pembelajaran kontekstual CTL (Contextual Teaching and Learning) adalah konsep belajar dengan berdasarkan penemuan yang bermakna, didapat dari transfer orang lain atau yang dibangun dari siswa sendiri. Metode pembelajaran kontekstual (Contextual Teaching and Learning) adalah suatu metode pembelajaran yang selalu menyatu dengan tempat belajar, waktu, situasi dan suasana alam dan masyarakatnya (Subyantoro, 2004). Dalam model pembelajaran kontekstual ini siswa diorientasikan pada proses pengalaman secara langsung, baik di dalam kelas, maupun di luar kelas, sehingga siswa dapat menangkap hubungan antara pengalaman belajar di sekolah dan kehidupan nyata dan menerapkannya dalam kehidupan. Agar pembelajaran menjadi bermakna, materi pelajaran haruslah disesuaikan dan diangkat dari konteks aktual yang dialami siswa dalam kehidupannya.

Variabel minat belajar merupakan dorongan untuk menjadi giat belajar dengan cara fokus terhadap apa yang dilakukan dan menggapai apa yang dinginkan. Minat belajar akan melahirkan perhatian, memudahkan terciptanya konsentrasi, mencegah gangguan perhatian dari luar, melekatnya bahan pelajaran dalam ingatan, memperkecil kebosanan studi dalam diri sendiri.

Pengujian pengaruh model pembelajaran kontekstual dan minat belajar terhadap kemampuan menulis puisi dilakukan dengan mengajukan dan menguji sejumlah hipotesis (seperti pada tabel 1 di bawah ini )

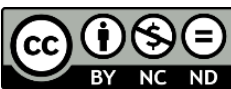




\section{Tabel 1. Tests of Between-Subjects Effects}

Dependent Variable: kemampuan menulis puisi

\begin{tabular}{|l|l|r|r|r|r|}
\hline Source & \multicolumn{1}{|c|}{$\begin{array}{c}\text { Type III Sum of } \\
\text { Squares }\end{array}$} & df & Mean Square & \multicolumn{1}{|c|}{ F } & Sig. \\
\hline Corrected Model & $4097,334^{\mathrm{a}}$ & 3 & 1365,778 & 100,079 &, 000 \\
Intercept & 453712,626 & 1 & 453712,626 & 33246,407 &, 000 \\
E1 & 3098,805 & 1 & 3098,805 & 227,069 &, 000 \\
E2 & 943,251 & 1 & 943,251 & 69,118 &, 000 \\
E1 $*$ E2 & 55,278 & 1 & 55,278 & 4,051 &, 048 \\
Error & 1037,170 & 76 & 13,647 & & \\
Total & 458847,130 & 80 & & & \\
Corrected Total & 5134,504 & 79 & & & \\
\hline
\end{tabular}

a. R Squared $=, 798$ (Adjusted R Squared $=, 790)$

Instrumen penelitian untuk masing-masing variabel adalah angket dan instrumen tes kepada siswa saat penelitian berlangsung. Selanjutnya, data dianalisis dengan bantuan software SPSS 20.0.

\section{HASIL DAN PEMBAHASAN}

Berdasarkan hasil penelitian, model pembelajaran memberikan pengaruh yang positif terhadap kemampuan menulis puisi siswa. Berdasarkan tabel 2, hasil ANOVA dengan nilai $\mathrm{F}_{0}=227,069$ dan Sig. $=0,000<0,05$, ini berarti hipotesis null $\left(\mathrm{H}_{0}\right)$ ditolak dan hipotesis alternatif $\left(\mathrm{H}_{1}\right)$ diterima. Maka terdapat pengaruh yang signifikan antara model pembelajaran dan kemampuan menulis puisi siswa; atau dengan kata lain, terdapat hasil berbeda pada kemampuan menulis puisi siswa yang menggunakan model pembelajaran kontekstual dan model pembelajaran konvensional.

Berdasarkan hasil penelitian minat belajar memberikan pengaruh yang positif terhadap kemampuan menulis puisi siswa. Berdasarkan tabel 2, hasil ANOVA dengan nilai $\mathrm{F} 0=69,118$ dan Sig. $=0,000<0,05$, ini berarti hipotesis nol (H0) ditolak dan hipotesis alternatif (H1) diterima. Maka terdapat pengaruh yang signifikan minat belajar terhadap kemampuan menulis puisi siswa; atau dengan kata lain, terdapat hasil berbeda pada kemampuan menulis puisi siswa yang memiliki minat belajar tinggi dan rendah.

Berdasarkan hasil penelitian, model pembelajaran dan minat belajar memberikan pengaruh yang positif terhadap kemampuan menulis puisi siswa. Berdasarkan tabel 2, hasil ANOVA dengan nilai $\mathrm{F}_{0}=4,051$ dan Sig. $=0,048<0,05$, ini berarti hipotesis nol $\left(\mathrm{H}_{0}\right)$ ditolak dan hipotesis alternatif $\left(\mathrm{H}_{1}\right)$ diterima. Maka terdapat pengaruh interaksi yang signifikan model pembelajaran dan minat belajar terhadap kemampuan menulis puisi siswa. Sementara itu nilai Adjused R. Squared adalah 0,798; ini berarti bahwa model pembelajaran dan minat belajar memberikan pengaruh $79,8 \%$ pada kemampuan menulis puisi siswa. 


\section{Tabel 2. Dependent Variable: Kemampuan Mengarang Narasi} Tests of Between-Subjects Effects

Dependent Variable: Kemampuan Mengarang Narasi
\begin{tabular}{|l|r|r|r|r|r|}
\hline Source & $\begin{array}{r}\text { Type III Sum of } \\
\text { Squares }\end{array}$ & df & Mean Square & F & \multicolumn{1}{c|}{ Sig. } \\
\hline Corrected Model & 4097,334 & 3 & 1365,778 & 100,079 &, 000 \\
Intercept & 453712,626 & 1 & 453712,626 & 33246,407 &, 000 \\
Model_Pembelajaran & 3098,805 & 1 & 3098,805 & 227,069 &, 000 \\
Minat_Belajar & 943,251 & 1 & 943,251 & 69,118 &, 000 \\
Model_Pembelajaran* & 55,278 & 1 & 55,278 & 4,051 &, 048 \\
Minat_Belajar & 1037,169 & 76 & 13,647 & & \\
Error & 458847,130 & 80 & & & \\
Total & 5134,504 & 79 & & & \\
Corrected Total & & & & \\
\hline
\end{tabular}

a. $\quad$ R Squared $=, 798$ (Adjusted R Squared $=, 790$ )

Kemampuan menulis puisi sekolah menengah pertama di kecamatan Cibinong Kabupaten Bogor dipengaruhi oleh model pembelajaran kontekstual dan minat belajar siswa. Model pembelajarn kontekstual memiliki peran terhadap pengembangan minat belajar siswa. Semakin baik model pembelajarn kontekstual yang digunakan oleh guru, semakin baik pula minat belajar siswa. Lebih lanjut, model pembelajaran kontekstual berperan positif terhadap peningkatan minat belajar siswa.

Belajar adalah usaha aktif yang dilakukan siswa di bawah bimbingan guru. Siswa sebagai peserta didik diharapkan mampu berinteraksi secara aktif dengan seluruh proses yang berlangsung. Selanjutnya, siswa berusaha menyerap dan menguasai pengetahuan dan keterampilan dari pengalaman belajar yang dilalui. Sikap dan perilaku belajar yang mendukung pengalaman belajar yang baik dapat diperoleh dengan didukung minat belajar.

Minat belajar merupakan sesuatu yang dapat membangkitkan atau mendorong seseorang untuk menajadi giat belajar dalam mencapai cita-cita yang diinginkan, yaitu berusaha untuk mengetahui suatu pelajaran dengan cara mengetahui, mengikuti, memahami pelajaranm memusatkan perhatian, belajar lebih giat, dan akhirnya mencapai prestasi yang diinginkan. Minat belajar akan melahirkan perhatian, memudahkan terciptanya konsentrasi, mencegah gangguan perhatian dari luar, memperkuat melekatnya bahan pelajaran dalam ingatan, dan memperkecil kebosanan studi dalam diri sendiri

Minat belajar merupakan aspek psikologi seseorang yang menampakkan diri dalam beberapa gejala, seperti: gairah, keinginan, perasaan suka untuk melakukan proses perubahan tingkah laku melalui berbagai kegiatan yang meliputi mencari pengetahuan dan pengalaman. Dengan kata lain, minat belajar itu adalah perhatian, rasa suka, ketertarikan seseorang (siswa) terhadap aktivitas belajar yang ditunjukkan melalui keantusiasan, partisipasi, dan keaktivan dalam belajar serta menyadari pentingnya kegiatan itu. Selanjutnya, terjadi perubahan dalam diri siswa yang berbentuk keterampilan, sikap, kebiasaan, pengetahuan, kecakapan, dan pengalaman belajar. Minat siswa untuk belajar mempunyai pengaruh yang besar terhadap keberhasilan belajar karena minat siswa merupakan faktor utama yang 
menentukan derajat keaktivan siswa. Bila bahan pelajaran yang dipelajari tidak sesuai dengan minat siswa, maka siswa tidak akan belajar dengan sebaik-baiknya sebab tidak ada daya tarik baginya. Oleh karena itu, untuk mengatasi siswa yang kurang berminat dalam belajar, guru hendaknya berusaha bagaimana menciptakan kondisi tertentu agar siswa itu selalu membutuhkan dan ingin terus belajar. Minat belajar sangat mendukung dan mempengaruhi pelaksanan proses belajar mengajar di sekolah yang akhirnya bermuara pada pencapaian tujuan pembelajaran.

\section{SIMPULAN}

Berdasarkan hasil penelitian yang dilakukan, dapat disimpulkan bahwa kemampuan menulis puisi sekolah menengah pertama di kecamatan Cibinong Kabupaten Bogor dipengaruhi oleh model pembelajaran kontekstual dan minat belajar siswa. Model pembelajaran kontekstual memiliki peran terhadap pengembangan minat belajar siswa. Semakin baik model pembelajarn kontekstual yang digunakan oleh guru, semakin baik pula minat belajar siswa. Lebih lanjut, model pembelajaran kontekstual berperan positif terhadap peningkatan minat belajar siswa.

\section{DAFTAR PUSTAKA}

Abidin, Y. (2009). Kemampuan menulis dan berbicara akademik. Bandung: Risqi Press.

Ardiana, L. I. (2001). Pembelajaran kontekstual.

Jabrohim, Anwar, \& Sayuti. (2009). Cara menulis kreatif. Yogyakarta: Pustaka Pelajar.

Kartika, L. M. (2014). Pembelajaran keterampilan menulis di kelas VIII SMP Negeri 1 Bantul. Universitas Negeri Yogyakarta.

Musaljon. (2019). Pengaruh persepsi atas metode pembelajaran kontekstual dan media pembelajaran terhadap kemampuan mengarang narasi siswa Smk Putra Bangsa Kota Depok. INA-Rxiv. April. Retrieved from https://osf.io/d7h6y/download/?format=pdf.

Pradopo, R. D. (2000). Pengkajian puisi: Analisis strata norma dan analisis struktural dan semiotik. Yogyakarta: Gajah Mada University Press.

Sanjaya, W. (2008). Pembelajaran dalam implementasi kurikulum berbasis kompetensi. Jakarta: Kencana.

Sari, N. (2017). Kekerasan perempuan dalam novel Bak Rambut Dibelah Tujuh karya Muhammad Makhdlori. LITERASI, 1(2), 41-48. Retrieved from https://jurnal.unigal.ac.id/index.php/literasi/article/view/792

Subyantoro. (2004). Materi pelatihan terintegrasi bahasa Indonesia (Pengembangan materi media pembelajaran bahasa dan sastra Indonesia). Jakarta: Depdiknas.

Tarigan, H. G. (1994). Menulis sebagai suatu keterampilan berbahasa. Bandung: Angkasa. 